\title{
Comparing spring triticale varieties to barley and wheat varieties when harvested as whole crop
}

\author{
${ }^{1}$ Katariina Manni, ${ }^{2}$ Timo Lötjönen and ${ }^{3}$ Arto Huuskonen \\ ${ }^{1}$ Natural Resources Institute Finland (Luke), Production Systems, Tietotie 2 C, FI-31600 Jokioinen, Finland \\ ${ }^{2}$ Natural Resources Institute Finland (Luke), Production Systems, Paavo Havaksentie 3, FI-90570 Oulu, Finland \\ ${ }^{3}$ Natural Resources Institute Finland (Luke), Production Systems, Halolantie 31 A, FI-71750 Maaninka, Finland \\ e-mail: katariina.manni@luke.fi
}

\begin{abstract}
Two plot experiments in two consecutive years were conducted to compare spring triticale varieties to spring barley and spring wheat varieties to produce whole crop cereals for ruminants. In the first year, triticale varieties Nagano and Nilex, barley varieties Kaarle and Trekker and the wheat variety Helmi were studied. In the second year, the triticale varieties Bikini and Somtri and the barley variety Armas were also used. The crops were harvested at the early dough stage of ripening. A treatment with reduced fertilizer and seed rates were included to study their effects on the development of the undersown ley, but such effects could not be demonstrated. The triticale varieties except for Bikini produced high dry matter yields. The highest ear:stem ratio and pepsin-cellulase solubility in the ear were found in the barley varieties Armas and Kaarle, but the digestibility of the whole crop was not improved because of low pepsin-cellulase solubility of the stems or leaves. All the studied varieties were suitable for whole crop production. The production costs of the different types of whole crop silage were fairly similar.
\end{abstract}

Key words: feed, forage, $X$ Triticosecale, Hordeum vulgare, Triticum aestivum, digestibility

\section{Introduction}

Small grain cereal-based whole crop silage provides an opportunity to improve the efficiency of forage production for ruminants under Nordic conditions (Rustas 2009). They can be used for both dairy and beef cattle by mixing them with grass silage or as a sole forage, depending on the quality of feed and nutrient requirements of the cattle (Keady 2005, Huuskonen and Joki-Tokola 2010). Whole crop silage has the potential to lower costs, which has increased the interest in using them for cattle feeding. A high dry matter (DM) yield at a single harvest is one advantage which reduces the costs compared to grass silage. Additionally, spring cereals can be grown in different climatic and soil conditions, and as annual crops there is no risk of a winter kill. They also can be used as nurse crops for undersown new leys. The advantage of this is that early harvesting of the whole crop promotes grass growth in the autumn. Cereals fit well in crop rotations at grass dominated farms, provide opportunities for manure spreading in spring, and the same harvesting and ensiling technology as for grasses can be used. The digestibility of whole crop silage is typically lower than that of grass silage, which may limit the use in feeding, but a higher DM intake may compensate for this (Sinclair et al. 2003, Keady 2005, Huhtanen et al. 2007, Huuskonen et al. 2020).

Barley (Hordeum vulgare), oats (Avena sativa), and wheat (Triticum aestivum) are commonly used for the production of whole crop silage in Nordic conditions. Triticale ( $X$ Triticosecale) is commonly grown for grain production in Europe up to Denmark (Peltonen-Sainio et al. 2009), but it is a fairly new crop in Finland. Its high DM yield potential has recently increased the interest in cultivating it. However, because triticale requires rather long growing season for ripening, it is commonly harvested at an earlier growth stage as whole crop silage instead of harvesting the grains in northern regions. In an experiment by Nadeau (2007), winter triticale and spring wheat had a greater DM yield than oats and barley when harvested as a whole crop at the early dough stage of maturity.

When comparing small grain cereal species, they can vary in the proportion of morphological fractions (Khorasani et al. 1997) and feed quality (Cherney and Marten 1982, Nadeau 2007, Huuskonen et al. 2017, Huuskonen et al. 2020). Khorasani et al. (1997) found that spring triticale had the highest stem proportion, but the ear proportion did not differ when compared to barley, oats and crop mixtures of barley and winter triticale. The leaf proportion of triticale was lower than for barley and crop mixtures. In previous experiments it has been found a higher digestibility for barley than triticale and wheat (Cherney and Marten 1982, Huuskonen et al. 2017, Huuskonen et al. 2020) but Nadeau (2007) observed that both barley and triticale had higher in vitro digestibility than oats and wheat. Also, differences in chemical composition of different whole crop silages, like barley, triticale, oats and wheat, has been found (Nadeau 2007, Huuskonen et al. 2017, Huuskonen et al. 2020). 
Many experiments have been conducted to evaluate the potential of small grain cereals as a raw material for whole crop silage, but there is lack of information on the yields and feed quality of spring triticale. Furthermore, there is inadequate information concerning the differences between crop varieties in terms of the yield and feed quality, especially for spring triticale varieties when used as a raw material for whole crop silage production. The objective of this experiment was to compare triticale, barley, and wheat varieties as a raw material for whole crop silage when harvested at an early dough stage of ripening. Yield, nutritive values, and fractions of the stem, leaves and ears were determined. Furthermore, the effects on establishing new leys were evaluated when cereal crops were used as the nurse crops for undersown leys under normal and reduced seed and fertilization rates and harvested as a whole crop. In addition, there is lack of information whether the production costs of different type of whole crop silages differ from costs of grass silage in typical Finnish production systems. For this need the production costs were calculated for the various types of whole crop silage. It was hypothesized that triticale varieties would produce higher whole crop yields than varieties of barley and wheat. It was also hypothesized that reduced seed and fertilization rates could prevent crop lodging and promote grass growth.

\section{Material and methods}

\section{Plant material and experimental design}

The plot experiments were conducted during two growing seasons, in 2017 and 2018, at the Research Station of the Natural Resources Institute Finland (Luke) in Ruukki ( $\left.64^{\circ} 44^{\prime} \mathrm{N}, 25^{\circ} 15^{\prime} \mathrm{E}\right)$. The soil type was sandy loam. In 2017, two varieties of triticale (Nagano, Nilex), two varieties of barley (Kaarle, Trekker), and one variety of wheat (Helmi) were used. In 2018, four triticale varieties (Bikini, Nagano, Nilex, Somtri), three barley varieties (Armas, Kaarle, Trekker), and one wheat variety (Helmi) were used. All varieties were spring types. The aim was to study such varieties which are potential for whole crop production and which are suitable for growing in northern climate conditions. The recommendations of the plant breeders and seed companies were taken into account when the varieties were chosen. The experimental design with four replicates was a split-plot in 2017, and a randomized complete block in 2018. The plot representing the plant variety was $1.5 \times 10 \mathrm{~m}$. The experiment was sown on 24 May 2017 and on 5 June 2018. The seed rate was 500 seeds $\mathrm{m}^{-2}$ for all varieties, with the exception of the Helmi wheat variety which had a seed rate of 650 seeds $\mathrm{m}^{-2}$.

In 2017, the soil pH was 6.1 and the concentrations of calcium (Ca), potassium (K), phosphorus (P), magnesium $(\mathrm{Mg})$ and sulfur (S) were 1400, 75, 14, 96 and $10 \mathrm{mg} \mathrm{l}^{-1}$, respectively. In 2018, the soil pH was 6.2 and the concentrations of $\mathrm{Ca}, \mathrm{K}, \mathrm{P}, \mathrm{Mg}$ and S were 1600, 110, 15, 130 and $12 \mathrm{mg} \mathrm{l}^{-1}$, respectively. As the values showed insufficient contents of $\mathrm{K}$ in the soil, a $\mathrm{K}$ rich fertilizer was used. Artificial NPK fertilizer was applied during sowing with $90 \mathrm{~kg} \mathrm{~N} \mathrm{ha}^{-1}, 9 \mathrm{~kg} \mathrm{P} \mathrm{ha}^{-1}$ and $54 \mathrm{~kg} \mathrm{~K} \mathrm{ha}^{-1}$. The plots were rolled after sowing. In 2017, weeds were controlled with a mixture of sulphonyl ureas and MCPA. In 2018 weed control was not necessary. Insect or plant disease control was not needed, and plant growth regulators were not used. The crops were harvested at $5 \mathrm{~cm}$ stubble height at the early dough stage of ripening (growth stage Z83; Zadoks et al. 1974) using a Haldrup plot harvester equipped with a scale. In 2017 and 2018, all varieties were harvested in August (Table 1).

Table 1. Harvest dates for whole crop cereals harvested at the early dough stage in 2017 and 2018. The crops were sown on 24 May 2017 and 5 June 2018. Temperature sums (degree days, $\mathrm{DD}+5^{\circ} \mathrm{C}$ ) between sowing and harvest are presented (source: Finnish Meteorological Institute).

\begin{tabular}{llccccc}
\hline \multirow{2}{*}{ Crop species } & Crop variety & \multicolumn{2}{c}{ Harvest date } & & \multicolumn{2}{c}{ Temperature sum (DD), ${ }^{\circ} \mathrm{C}$} \\
\cline { 3 - 4 } \cline { 5 - 6 } Barley & Armas & - & 2017 & & 2017 & 2018 \\
Barley & Kaarle & 16.8. & 10.8. & & 685 & 788 \\
Barley & Trekker & 21.8. & 10.8. & & 738 & 788 \\
Wheat & Helmi & 25.8. & 21.8. & & 760 & 788 \\
Triticale & Bikini & - & 27.8. & & 892 \\
Triticale & Nagano & 29.8. & 27.8. & & 780 & 940 \\
Triticale & Nilex & 29.8. & 27.8. & 780 & 940 \\
Triticale & Somtri & - & 27.8. & & 940 \\
\hline
\end{tabular}


Establishing a new ley using cereals as nurse crops at normal and reduced fertilization and seed rate was also studied. In 2017, both fertilizer and seed rate were reduced by $30 \%$ of the normal rates reported above and they were analyzed as one treatment. An NPK fertilizer was applied at $63 \mathrm{~kg} \mathrm{~N} \mathrm{ha}^{-1}$ and the seed rate was 350 seeds m², with the exception of the Helmi variety which was sown at a seed rate of 455 seeds $\mathrm{m}^{-2}$. The ley was established at the same time with sowing crops. The seed mixture contained timothy (Phleum pratense), meadow fescue (Festuca pratensis), and red clover (Trifolium pratense), and their seed rates were 15, 5 and $5 \mathrm{~kg} \mathrm{ha}^{-1}$, respectively. In 2018, the primary growth and regrowth of grass was harvested on 26 June and 21 August, respectively, using a Haldrup plot harvester and at both harvests, the biomass yield was determined. The DM yield of the primary growth and regrowth were analyzed separately, and also the total DM yield was analyzed.

Production costs were calculated for whole crop barley silage, triticale silage, faba bean-wheat silage, and clover-timothy silage. The production costs were calculated by utilizing model calculations by ProAgria Advisory Services and contractor prices for the machine work collected by TTS (Palva 2019, ProAgria 2019).

The yield ranges of the current study were used for the whole crop cereals, while those by Hakala et al. (2012) were used for grass silage, and those by Kuoppala et al. $(2014,2015)$ were used for faba bean-wheat silage. The used DM yields in the calculations represented fresh whole crop DM yields without harvest, storage and ensiling losses. Clover-timothy ley was assumed to be undersown with the nurse crop and it was expected to be grown for three years. The costs of establishing ley included seed costs but not machinery costs. Faba bean-wheat crop and grass were assumed to be harvested with a disc mower and pick up forage harvester, while barley and triticale crops was assumed to have been cut with a direct cut forage harvester. The direct cut harvester has the lowest harvest losses when harvesting grain or pulse crops, but faba bean whole crop is usually so wet that a better silage quality is achieved when the swaths are allowed to wilt on the field before ensiling (Kuoppala et al. 2014, 2015). All types of silage were assumed to be stored in clamp silos. The machine work, including transportation of the feeds, filling and sealing of silo, were assumed to have been carried out by contractors and they were not included the calculation. The interest on the working capital was calculated based on variable costs assuming that the capital was invested in production for half a year (50\%) and by using a $5 \%$ interest level.

\section{Feed analyses and measurements}

During harvesting, the yield of all plots was weighed and samples were taken for chemical analyses. The samples were dried at $60^{\circ} \mathrm{C}$ for three days to determine the DM concentration and for later analyses. Ash, crude protein $(C P)$, neutral detergent fiber (NDF), indigestible NDF (iNDF), water-soluble carbohydrates (WSC), and digestible organic matter (DOM) in the DM (DOMD, D-value) were analyzed using the near infrared (NIR) spectroscopy (FOSS NIRSystems 6500 spectrometer, Denmark) at the laboratory of Valio Ltd. Seinäjoki, Finland. The device was calibrated for measuring chemical composition of whole crop silages.

The metabolizable energy (ME) concentration of the samples was calculated as $M E\left(\mathrm{MJ} \mathrm{kg}^{-1} \mathrm{DM}\right)=15.5 \times \mathrm{DOMD}$ ( $\left.\mathrm{kg} \mathrm{kg}^{-1} \mathrm{DM}\right)$ (MAFF 1984). The protein value of the samples is expressed as the amino acids absorbed from the small intestine (metabolizable protein, MP) and the protein balance in the rumen (PBV) according to Luke (2020).

After harvesting the whole crop samples were frozen and during the winter 2018-2019 stem, leaf and ear fractions were separated manually. The fractions were dried at $60^{\circ} \mathrm{C}$ for three days to determine the DM concentration. The proportion of the fractions was measured on a DM basis. The ash concentration of the fractions was determined by ashing at $600{ }^{\circ} \mathrm{C}$ for $2 \mathrm{~h}$. The starch concentration of the ears was analyzed according to Salo and Salmi (1968). The digestibility of the fractions was based on the in vitro pepsin-cellulase solubility (Nousiainen et al. 2003, Huhtanen et al. 2006).

The sward density, which describes the coverage of the grass, was measured in spring when grass growth had begun. The density (\%) was evaluated by using a scale 0 to 100 ( $0=$ totally destroyed, $100=$ fully covered).

The temperature sum (degree days, $\mathrm{DD}+5^{\circ} \mathrm{C}$ ) and precipitation were measured during the growing season from May to September. A meteorological station of the Finnish Meteorological Institute, which automatically provides data of daily temperature and rainfall is located at the Research Station in Ruukki. 


\section{Statistical methods}

The normality of the analyzed variables was checked using graphical methods: these included box- and scatter-plots of the residuals and fitted values. The data were subjected to an analysis of variance using the SAS MIXED procedure (version 9.4, SAS Institute Inc., Cary, NC, USA). The data from each year were analyzed and presented separately. In 2017, the experimental design was a split-plot with four replicates with a randomized complete block arrangement of treatments. The main block consisted of the combined effect of reduced fertilizer rate and reduced seed rate and the effect of variety was treated as the sub-plot. Crop varieties were randomized in the main blocks. In 2017, only three replicates were used for the DM yield due to the outlier observations in one replicate.

In 2017, the data were analyzed for a split-plot design using the statistical model

$y_{i j k}=\mu+\rho_{i}+\alpha_{j}+w_{i j}+\beta_{k}+(\alpha \times \beta)_{j k}+\varepsilon_{i j k}$

where $\mu$ is the overall mean and $\alpha_{j} \beta_{k}$ and $(\alpha \times \beta)_{j k}$ are the combined fixed effects of the fertilizer and seed rate, plant variety and their interaction, respectively, $\rho_{\mathrm{i}}$ is the random effect of the block, $\mathrm{w}_{\mathrm{ij}}$ is the residual error term of the combined fertilizer and seed rate, and $\varepsilon_{\mathrm{ijk}}$ is the residual error term of the plant variety.

In 2018, the data were analyzed for a randomized complete block design using the statistical model

$y_{i j}=\mu+\rho_{i}+\tau_{j}++\varepsilon_{i j}$

where $\mu$ is the overall mean and $\tau_{\mathrm{j}}$ is the fixed effect of the plant variety, $\rho_{\mathrm{i}}$ is the random effect of the block, and $\varepsilon_{\mathrm{ij}}$ is the residual error term of the plant variety and block.

Differences between the treatments were tested using Tukey's test. The results were considered statistically significant when $p<0.05$, which was used to determine significant differences between the means in the main effects for the plant varieties, combined fertilizer and seed rate, and in interactions between plant varieties and combined fertilizer and seed rates.

\section{Results}

\section{Weather conditions}

The temperature sum during the growing season in 2017 was slightly lower than average, whereas in 2018 it was considerably higher than average (Table 2). The precipitation sum from May to July in 2017 was close to the long term average, but in August it was considerably higher (Table 2). The precipitation during the growing season in 2018 was below average and July especially was dry.

Table 2. Temperature sum (degree days, $\mathrm{DD}+5^{\circ} \mathrm{C}$ ) and precipitation at the Research Station in Ruukki $\left(64^{\circ} 44^{\prime} \mathrm{N}, 25^{\circ} 15^{\prime} \mathrm{E}\right)$ in 2017-2018 compared to the long term average during 1981-2010 (source: Finnish Meteorological Institute)

\begin{tabular}{|c|c|c|c|c|c|c|}
\hline & \multicolumn{3}{|c|}{ Temperature sum (DD), ${ }^{\circ} \mathrm{C}$} & \multicolumn{3}{|c|}{ Precipitation, mm } \\
\hline & 2017 & 2018 & 1981-2010 & 2017 & 2018 & 1981-2010 \\
\hline May & 41 & 211 & 95 & 37 & 23 & 42 \\
\hline June & 213 & 216 & 244 & 41 & 45 & 50 \\
\hline July & 310 & 466 & 338 & 77 & 25 & 77 \\
\hline August & 265 & 322 & 263 & 122 & 87 & 71 \\
\hline September & 110 & 171 & 113 & 38 & 58 & 50 \\
\hline Total (May-September) & 938 & 1386 & 1052 & 315 & 237 & 289 \\
\hline
\end{tabular}

\section{Yields of whole crops}

For the DM yield, no significant fertilizer and seed rate $\times$ variety interaction was observed in 2017 (Table 3). The treatment with reduced fertilizer and seed rate decreased $(p<0.001)$ average whole crop yield by $13 \%$ ( 9539 vs. $\left.8299 \mathrm{~kg} \mathrm{ha}^{-1}\right)$. When comparing varieties across fertilizer and seed rates, the triticale variety Nagano yielded the highest $(p<0.05)$ result. The DM yield between varieties varied from 8650 to $9427 \mathrm{~kg} \mathrm{ha}^{-1}$. 
Table 3. Yield, chemical composition, and feed values of whole crops at normal or reduced (30\% of the normal level) fertilizer and seed rate and for different varieties of barley, triticale and wheat harvested at the early dough stage and in 2017

\begin{tabular}{|c|c|c|c|c|c|c|c|c|c|c|c|}
\hline & \multicolumn{2}{|c|}{$\begin{array}{l}\text { Fertilizer and seed } \\
\qquad \text { rate }^{1}\end{array}$} & \multicolumn{2}{|c|}{ Triticale } & \multicolumn{2}{|c|}{ Barley } & \multirow{2}{*}{$\begin{array}{c}\text { Wheat } \\
\text { Helmi }\end{array}$} & \multirow[b]{2}{*}{$\mathrm{SEM}^{2}$} & \multicolumn{3}{|c|}{$p$-values ${ }^{3}$} \\
\hline & Normal & Reduced & Nagano & Nilex & Kaarle & Trekker & & & $\begin{array}{l}\text { Fertilizer and } \\
\text { seed rate }\end{array}$ & Variety & Interaction ${ }^{4}$ \\
\hline $\begin{array}{l}\text { Yield, kg } \\
\text { dry matter } \\
\text { (DM) ha-1 }\end{array}$ & $9539^{a}$ & $8299^{b}$ & $9427^{a}$ & $8808^{b}$ & $8927^{b}$ & $8650^{b}$ & $8785^{b}$ & 102.7 & $<0.001$ & $<0.001$ & 0.119 \\
\hline \multicolumn{12}{|c|}{ Chemical composition, $\mathrm{g} \mathrm{kg}^{-1} \mathrm{DM}$} \\
\hline Crude protein & $87^{\mathrm{a}}$ & $81^{b}$ & $85^{\mathrm{ab}}$ & $84^{\mathrm{ab}}$ & $81^{b}$ & $83^{\mathrm{ab}}$ & $87^{\mathrm{a}}$ & 1.6 & 0.023 & 0.049 & 0.279 \\
\hline $\begin{array}{l}\text { Neutral } \\
\text { detergent } \\
\text { fibre (NDF) }\end{array}$ & 461 & 458 & $473^{a}$ & $477^{a}$ & $441^{b}$ & $419^{b}$ & $487^{a}$ & 7.3 & 0.551 & $<.0001$ & 0.931 \\
\hline $\begin{array}{l}\text { Indigestible } \\
\text { NDF }\end{array}$ & 150 & 149 & $161^{a}$ & $160^{\mathrm{a}}$ & $141^{b}$ & $118^{c}$ & $166^{a}$ & 4.2 & 0.633 & $<.0001$ & 0.728 \\
\hline $\begin{array}{l}\text { Water soluble } \\
\text { carbohydrates }\end{array}$ & 154 & 164 & 198 & 212 & 113 & 115 & 157 & 2.7 & $<0.001$ & $<.0001$ & 0.008 \\
\hline Ash & 46 & 45 & $47^{\mathrm{ab}}$ & $46^{\mathrm{bc}}$ & $44^{\text {cd }}$ & $42^{d}$ & $49^{a}$ & 1.0 & 0.085 & $<.0001$ & 0.104 \\
\hline $\begin{array}{l}\text { Digestible } \\
\text { organic matter }\end{array}$ & 612 & 613 & $595^{c}$ & $598^{c}$ & $626^{b}$ & $654^{a}$ & $591^{c}$ & 4.8 & 0.764 & $<0.001$ & 0.604 \\
\hline \multicolumn{12}{|l|}{ Feed values } \\
\hline 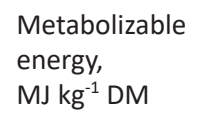 & 9.8 & 9.81 & $9.5^{c}$ & $9.6^{c}$ & $10.0^{b}$ & $10.5^{a}$ & $9.5^{c}$ & 0.08 & 0.821 & $<.0001$ & 0.776 \\
\hline $\begin{array}{l}\text { Metabolizable } \\
\text { protein, } \\
\mathrm{g} \mathrm{kg}^{-1} \text { DM }\end{array}$ & 69 & 68 & $67^{c}$ & $67^{c}$ & $70^{\mathrm{b}}$ & $72^{\mathrm{a}}$ & $67^{c}$ & 0.5 & 0.269 & $<.0001$ & 0.481 \\
\hline $\begin{array}{l}\text { Protein balance } \\
\text { in the rumen, } \\
\mathrm{g} \mathrm{kg}^{-1} \mathrm{DM}\end{array}$ & $-17^{a}$ & $-23^{b}$ & $-17^{a}$ & $-17^{a}$ & $-24^{b}$ & $-27^{b}$ & $-14^{\mathrm{a}}$ & 1.3 & 0.023 & $<.0001$ & 0.393 \\
\hline
\end{tabular}

In 2018, the DM yield between varieties varied from 7043 to $10622 \mathrm{~kg} \mathrm{ha}^{-1}$ (Table 4). Among the species, triticale variety Bikini had lower $(p<0.05)$ DM yield than that of other triticale varieties. Differences between barley varieties were not found. Compared to the barley and wheat varieties, the triticale variety Somtri had higher $(p<0.05)$ DM yield than the barley varieties Kaarle and Armas and the wheat variety Helmi. The triticale variety Bikini had lower $(p<0.05)$ DM yield than the barley variety Trekker.

\section{Chemical composition and feed values}

The chemical composition and feed values of the whole crops in 2017 are presented in Table 3. Except for the WSC concentration, no significant fertilizer and seed rate $\times$ variety interactions were observed. There were significant differences between varieties in all chemical composition parameters and feed values. The wheat variety Helmi had a $7 \%$ higher $(p<0.05)$ CP concentration than that of the barley variety Kaarle. The treatment with reduced fertilizer and seed rate decreased $(p<0.05)$ the CP concentration by $8 \%$ ( $\left.87 \mathrm{vs.} 81 \mathrm{~g} \mathrm{~kg}^{-1} \mathrm{DM}\right)$. The highest $(p<0.05)$ NDF and iNDF concentrations were for the wheat variety Helmi and both triticale varieties Nilex and Nagano.

The barley varieties Trekker and Kaarle had the lowest $(p<0.05)$ NDF concentrations and the Trekker variety had the lowest $(p<0.05)$ iNDF concentration among all the five varieties. For the WSC some significant fertilizer and seed rate $\times$ variety interactions $(p=0.008)$ were observed (Table 3, Fig. 1$)$. For the triticale variety Nagano the WSC concentration decreased when the fertilizer and seed rate was reduced while for the other varieties the effect was contrary. Both barley varieties Trekker and Kaarle had higher $(p<0.05) \mathrm{D}$-values and ME concentrations than the others, Trekker having the highest values. Numerically the differences in ash, MP and PBV concentrations were minor although some significant differences were observed between the varieties. 


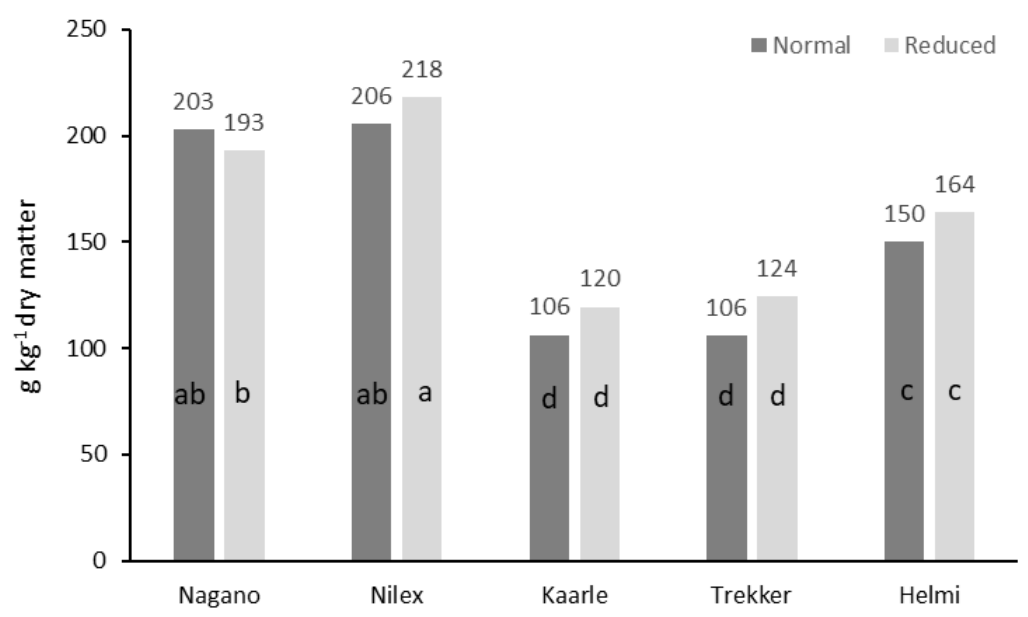

Fig. 1. Differences between varieties in water soluble carbohydrates ( $\mathrm{g} \mathrm{kg}^{-1} \mathrm{dry}$ matter), and the response to the amount of fertilizer and seed rate (normal vs. lower $30 \%$ of the normal level) when harvested at the early dough stage (interaction $p=0.008$; amount of fertilizer and seeding rate $\times$ varieties). Different letters in the bars indicate significant differences $(p<0.05)$ between means.

Chemical composition and feed values of the whole crops in 2018 are presented in Table 4. The CP concentration of the wheat variety Helmi was higher $(p<0.05)$ than that of all barley varieties, and higher than the triticale varieties Somtri and Nagano. Among the triticale varieties, the Somtri variety had a lower $(p<0.05)$ CP concentration compared to the varieties Nilex and Bikini but it did not differ from the Nagano variety. The triticale variety Nilex had lower $(p<0.05)$ NDF concentration compared to the triticale variety Somtri and the barley varieties Armas and Kaarle. The barley variety Trekker had lower $(p<0.05)$ iNDF concentration compared to the barley variety Kaarle and the triticale variety Somtri. Differences between varieties in terms of the D-value and ME concentrations were minor. The only significant difference $(p<0.05)$ was between the barley varieties Trekker (higher) and Kaarle (lower) both in their D-values and in ME concentrations.

Table 4. Dry matter yield, chemical composition, and feed values of different varieties of barley, triticale and wheat when harvested at the early dough stage in 2018

\begin{tabular}{|c|c|c|c|c|c|c|c|c|c|c|}
\hline \multirow[b]{2}{*}{ Variety } & \multicolumn{4}{|c|}{ Triticale } & \multicolumn{3}{|c|}{ Barley } & \multirow{2}{*}{$\begin{array}{l}\text { Wheat } \\
\text { Helmi }\end{array}$} & \multirow{2}{*}{ SEM $^{1}$} & \multirow{2}{*}{$p$-values ${ }^{2}$} \\
\hline & Bikini & Nagano & Nilex & Somtri & Armas & Kaarle & Trekker & & & \\
\hline Yield, kg dry matter (DM) ha-1 & $7043^{c}$ & $9483^{a b}$ & $9240^{\mathrm{ab}}$ & $10622^{\mathrm{a}}$ & $7901^{\text {bc }}$ & $7838^{b c}$ & $9092^{\mathrm{ab}}$ & $7650^{\mathrm{bc}}$ & 405.9 & $<0.001$ \\
\hline \multicolumn{11}{|l|}{ Chemical composition, $\mathrm{g} \mathrm{kg}^{-1} \mathrm{DM}$} \\
\hline Crude protein & $100^{\mathrm{ab}}$ & $90^{b c}$ & $99^{\mathrm{ab}}$ & $85^{c}$ & $89^{\mathrm{bc}}$ & $87^{c}$ & $94^{\mathrm{bc}}$ & $106^{a}$ & 2.8 & $<0.001$ \\
\hline Neutral detergent fibre (NDF) & $471^{\mathrm{ab}}$ & $468^{\mathrm{ab}}$ & $442^{b}$ & $508^{a}$ & $501^{\mathrm{a}}$ & $509^{a}$ & $465^{\mathrm{ab}}$ & $469^{\mathrm{ab}}$ & 12.4 & 0.003 \\
\hline Indigestible NDF (iNDF) & $148^{\mathrm{ab}}$ & $158^{\mathrm{ab}}$ & $148^{\mathrm{ab}}$ & $170^{\mathrm{a}}$ & $153^{\mathrm{ab}}$ & $167^{\mathrm{a}}$ & $136^{b}$ & $155^{\mathrm{ab}}$ & 6.8 & 0.010 \\
\hline Water soluble carbohydrates & $156^{\mathrm{a}}$ & $105^{\mathrm{ab}}$ & $119^{\mathrm{ab}}$ & $152^{\mathrm{a}}$ & $72^{\mathrm{b}}$ & $84^{b}$ & $106^{\mathrm{ab}}$ & $93^{b}$ & 11.8 & $<0.001$ \\
\hline Ash & $50^{\mathrm{b}}$ & $50^{b}$ & $51^{b}$ & $50^{\mathrm{b}}$ & $60^{\mathrm{a}}$ & $61^{\mathrm{a}}$ & $55^{\mathrm{ab}}$ & $55^{\mathrm{ab}}$ & 1.9 & 0.001 \\
\hline Digestible organic matter & $613^{\mathrm{ab}}$ & $602^{\mathrm{ab}}$ & $613^{\mathrm{ab}}$ & $592^{\mathrm{ab}}$ & $598^{\mathrm{ab}}$ & $580^{b}$ & $625^{a}$ & $603^{\mathrm{ab}}$ & 8.4 & 0.011 \\
\hline \multicolumn{11}{|l|}{ Feed values } \\
\hline $\begin{array}{l}\text { Metabolizable energy, } \\
\mathrm{MJ} \mathrm{kg}^{-1} \mathrm{DM}\end{array}$ & $9.8^{\mathrm{ab}}$ & $9.6^{\mathrm{ab}}$ & $9.8^{\mathrm{ab}}$ & $9.5^{\mathrm{ab}}$ & $9.6^{\mathrm{ab}}$ & $9.3^{b}$ & $10.0^{\mathrm{a}}$ & $9.7^{\mathrm{ab}}$ & 0.136 & 0.011 \\
\hline $\begin{array}{l}\text { Metabolizable protein, } \\
\mathrm{g} \mathrm{kg}^{-1} \mathrm{DM}\end{array}$ & $71^{\mathrm{ab}}$ & $68^{\mathrm{abc}}$ & $70^{\mathrm{ab}}$ & $67^{\mathrm{bc}}$ & $68^{\mathrm{abc}}$ & $66^{c}$ & $71^{\mathrm{a}}$ & $70^{\mathrm{ab}}$ & 1.0 & 0.002 \\
\hline $\begin{array}{l}\text { Protein balance in the } \\
\text { rumen, } \mathrm{g} \mathrm{kg}^{-1} \mathrm{DM}\end{array}$ & $-6^{a b}$ & $-13^{b c}$ & $-7^{a b}$ & $-16^{c}$ & $-13^{b c}$ & $-12^{\mathrm{bc}}$ & $-14^{\text {bc }}$ & $1^{\mathrm{a}}$ & 2.0 & $<0.001$ \\
\hline
\end{tabular}

${ }^{1}$ Standard error of mean; ${ }^{2}$ Means in the same row with different superscript letters are significantly different $(p<0.05)$ 


\section{Fractions}

The proportion, composition, and digestibility of fractions in the whole crops are presented in Table 5. The proportion of ear in the DM varied from 456 to $672 \mathrm{~g} \mathrm{~kg}^{-1} \mathrm{DM}$ between the varieties. Among the triticale varieties, Nagano and Nilex had higher $(p<0.05)$ proportion of ear than that of Bikini and Somtri. Bikini variety had the lowest $(p<0.05)$ proportion of ear compared to all other varieties. Among the barley varieties, Armas and Kaarle had higher $(p<0.05)$ proportion of ear than Trekker. The proportion of stems in the DM varied from 267 to $461 \mathrm{~g} \mathrm{~kg}^{-1}$ DM between the varieties. The triticale variety Bikini had a higher $(p<0.05)$ proportion than all other varieties. The proportion of leaves was clearly lower than for the ears or stems and it varied from 52 to $97 \mathrm{~g} \mathrm{~kg}^{-1} \mathrm{DM}$ between the varieties. The ear:stem ratio varied from 1.00 to 2.53 between the varieties. The highest $(p<0.05)$ ear:stem ratio was for the barley varieties Armas and Kaarle and the lowest $(p<0.05)$ was for the triticale varieties Bikini and Somtri.

Table 5. Proportion, composition, and digestibility of fractions for varieties of barley, triticale and wheat when harvested at the early dough stage in 2018.

\begin{tabular}{|c|c|c|c|c|c|c|c|c|c|c|}
\hline \multirow[b]{2}{*}{ Variety } & \multicolumn{4}{|c|}{ Triticale } & \multicolumn{3}{|c|}{ Barley } & \multirow{2}{*}{$\frac{\text { Wheat }}{\text { Helmi }}$} & \multirow{2}{*}{ SEM $^{1}$} & \multirow{2}{*}{$p$-values ${ }^{2}$} \\
\hline & Bikini & Nagano & Nilex & Somtri & Armas & Kaarle & Trekker & & & \\
\hline \multicolumn{11}{|l|}{ Fractions ${ }^{3}$} \\
\hline Proportion of ear, $\mathrm{g} \mathrm{kg}^{-1} \mathrm{DM}$ & $456^{\mathrm{e}}$ & $641^{\mathrm{abc}}$ & $597^{c}$ & $519^{d}$ & $672^{\mathrm{a}}$ & $662^{\mathrm{ab}}$ & $611^{c}$ & $623^{b c}$ & 9.9 & $<0.001$ \\
\hline Proportion of stem, $\mathrm{g} \mathrm{kg}^{-1} \mathrm{DM}$ & $461^{\mathrm{a}}$ & $307^{\text {cde }}$ & $338^{c}$ & $401^{b}$ & $267^{\mathrm{e}}$ & $269^{e}$ & $292^{\text {de }}$ & $309^{c d}$ & 8.6 & $<0.001$ \\
\hline Proportion of leaves, $\mathrm{g} \mathrm{kg}^{-1} \mathrm{DM}$ & $82^{\mathrm{ab}}$ & $52^{\mathrm{e}}$ & $65^{\text {cde }}$ & $79^{\mathrm{bc}}$ & $61^{\text {de }}$ & $70^{\mathrm{bcd}}$ & $97^{\mathrm{a}}$ & $68^{\mathrm{bcd}}$ & 3.3 & $<0.001$ \\
\hline Ear:stem ratio & $1.00^{d}$ & $2.09^{b}$ & $1.77^{c}$ & $1.30^{\mathrm{d}}$ & $2.53^{\mathrm{a}}$ & $2.47^{\mathrm{a}}$ & $2.09^{b c}$ & $2.02^{\mathrm{bc}}$ & 0.067 & $<0.001$ \\
\hline \multicolumn{11}{|l|}{ Ear } \\
\hline $\begin{array}{l}\text { Pepsin-cellulase solubility, } \\
\mathrm{g} \mathrm{kg}^{-1} \text { organic matter }\end{array}$ & $915^{d}$ & $947^{b}$ & $949^{b}$ & $936^{c}$ & $968^{a}$ & $974^{\mathrm{a}}$ & $953^{b}$ & $950^{b}$ & 3.0 & $<0.001$ \\
\hline Starch, $\mathrm{g} \mathrm{kg}^{-1} \mathrm{DM}$ & $365^{e}$ & $522^{\mathrm{ab}}$ & $538^{a}$ & $468^{d}$ & $483^{\text {cd }}$ & $505^{b c}$ & $487^{c d}$ & $499^{\mathrm{bc}}$ & 6.2 & $<0.001$ \\
\hline Ash, $\mathrm{g} \mathrm{kg}^{-1} \mathrm{DM}$ & $36^{a}$ & $29^{\text {de }}$ & $28^{\mathrm{e}}$ & $33^{b}$ & $31^{\text {bcd }}$ & $30^{\text {cde }}$ & $32^{\mathrm{bc}}$ & $28^{\text {de }}$ & 0.63 & $<0.001$ \\
\hline \multicolumn{11}{|l|}{ Stem } \\
\hline $\begin{array}{l}\text { Pepsin-cellulase solubility, } \\
\mathrm{g} \mathrm{kg}^{-1} \text { organic matter }\end{array}$ & $645^{a}$ & $539^{c}$ & $580^{b}$ & $580^{b}$ & $456^{d}$ & $455^{d}$ & $621^{\mathrm{a}}$ & $512^{c}$ & 6.4 & $<0.001$ \\
\hline Ash, $\mathrm{g} \mathrm{kg}^{-1} \mathrm{DM}$ & $43^{c d}$ & $51^{\mathrm{bc}}$ & $51^{\mathrm{bc}}$ & $40^{d}$ & $70^{\mathrm{a}}$ & $68^{\mathrm{a}}$ & $56^{\mathrm{b}}$ & $53^{b}$ & 2.2 & $<0.001$ \\
\hline \multicolumn{11}{|l|}{ Leaves } \\
\hline $\begin{array}{l}\text { Pepsin-cellulase solubility, } \\
\mathrm{g} \mathrm{kg}^{-1} \text { organic matter }\end{array}$ & $848^{a}$ & $817^{b c}$ & $843^{a b}$ & $839^{a b}$ & $786^{c}$ & $792^{c}$ & $842^{a b}$ & $801^{c}$ & 6.6 & $<0.001$ \\
\hline Ash, $\mathrm{g} \mathrm{kg}^{-1} \mathrm{DM}$ & $83^{c}$ & $100^{b}$ & $97^{b}$ & $82^{c}$ & $119^{a}$ & $127^{a}$ & $128^{\mathrm{a}}$ & $90^{\mathrm{bc}}$ & 2.5 & $<0.001$ \\
\hline
\end{tabular}

The starch concentration in the ears varied from 365 to $538 \mathrm{~g} \mathrm{~kg}^{-1} \mathrm{DM}$ between the varieties. The lowest $(p<0.05)$ starch concentration in the ears was for the triticale variety Bikini. The highest $(p<0.05)$ ash concentrations in the stems and leaves were found in the barley varieties, except in stems of Trekker.

The pepsin-cellulase solubility of the ears varied from 915 to $974 \mathrm{~g} \mathrm{~kg}^{-1}$ organic matter (OM). The highest $(p<0.05)$ solubility of the ears was found in the barley varieties Kaarle and Armas and the lowest $(p<0.05)$ was found for the triticale variety Bikini. For the stems, the pepsin-cellulase solubility was contrary to the solubility found for the ears. The highest $(p<0.05)$ solubility of the stems was found in the triticale variety Bikini and the barley variety Trekker, and the lowest $(p<0.05)$ was determined for the barley varieties Kaarle and Armas. Between the varieties, the solubility of the stems varied from 455 to $645 \mathrm{~g} \mathrm{~kg}^{-1} \mathrm{OM}$. For the leaves, the pepsin-cellulase solubility varied from 786 to $848 \mathrm{~g} \mathrm{~kg}^{-1} \mathrm{OM}$. Triticale variety Bikini had higher $(p<0.05)$ solubility of the leaves than that of triticale variety Nagano, barley varieties Armas and Kaarle and wheat variety Helmi. Barley varieties Armas and Kaarle and wheat variety Helmi as for had lower $(p<0.05)$ solubility of the leaves than that of all other varieties, except for triticale variety Nagano that did not differ from them. 


\section{Effects of fertilizer and seed rate on the yield of the ley}

In 2017 when the ley was established, the cereal crops did not lodge. The treatment with reduced fertilizer and seed rate increased $(p<0.05)$ the DM yield of the first cut and decreased $(p<0.05)$ the yield of the regrowth but it did not affect the total grass DM yield in the first grass production year (Table 6). The DM yield with normal fertilizer and seed rates was on average $7766 \mathrm{~kg} \mathrm{ha}^{-1}$ and at a reduced fertilizer and seed rate it was $7997 \mathrm{~kg} \mathrm{ha}^{-1}$.

Differences in the density of the ley sward in the spring were not found between the varieties or different fertilizer and seed rates (Table 6). The density of the ley sward in spring varied from 91 to $97 \%$ at the normal fertilizer and seed rates, and from 94 to $97 \%$ at the reduced fertilizer and seed rates.

Table 6. Dry matter (DM) yield of two cuts and density in spring of a ley stand in the first production year 2018 . The ley was established in 2017 with different varieties of triticale, barley, and wheat at normal or reduced ( $30 \%$ of the normal level) fertilizer and seeding rates and the crops were harvested as whole crops.

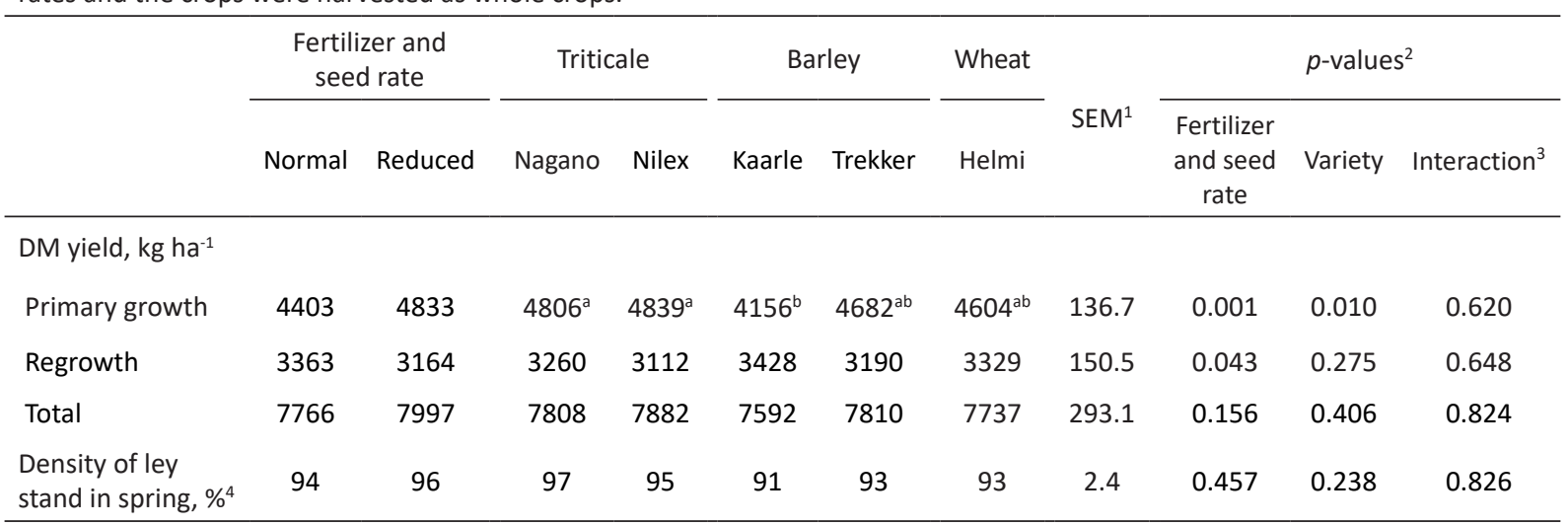

${ }^{1}$ Standard error of mean; ${ }^{2}$ Means in the same row with different superscript letters are significantly different $(p<0.05) ;{ }^{3}$ Interaction (whether amount of fertilization and seed rate has a different effect with varieties); ${ }^{4}$ Scale 0 to 100 ( $0=$ totally destroyed, $100=$ fully covered)

\section{Calculation of whole crop silage production costs}

The calculated production costs varied between $0.16-0.22 \mathrm{EUR} \mathrm{kg}^{-1} \mathrm{DM}$, when the crop yields varied between 6500-10000 kg DM ha-1 (Appendix). If mean yield levels were used, the costs of different type of silages did not differ considerably, being $0.18-0.19 \mathrm{EUR} \mathrm{kg}^{-1} \mathrm{DM}$.

Harvest and fertilizer costs were nearly double for clover-timothy silage compared to whole crop silage. The seed, tillage, and sowing costs were higher for the whole crop silage, because the costs occur annually for them.

\section{Discussion \\ Yields of the whole crops}

The high DM yield potential of triticale is one reason that there is interest in cultivating it in northern regions. As was found in the experiment by Nadeau (2007), triticale and spring wheat had greater DM yields than oats and barley when harvested as a whole crop at the early dough stage of maturity. However, contrary to the hypothesis and results by Nadeau et al. (2007), in the present experiment there was no clear evidence that triticale varieties produced higher whole crop yields compared to barley and wheat varieties. Based on results from one year, the Bikini variety produced lower DM yields than other triticale varieties. However, due to the rather extensive dispersion in the data in 2018, it makes difficult to interpret the results. There are also experiments where the DM yield of spring triticale has been lower than other crops (Berkenkamp and Meeres 1987, Khorasani et al. 1997). The differences between the studies may be related to several factors, e.g. weather conditions, soil type and the varieties studied.

\section{Chemical composition, feed values and fractions}

It is well established that increased $\mathrm{N}$ fertilizer increases the CP concentration of whole crops (Cazzato et al. 2012, Li et al. 2016), which is in line with the present experiment in 2017. However, in both years the CP concentration was rather low in all crop varieties and the differences between them were minor. Contrary to Nadeau (2007), 
there was no evidence in the present experiment that triticale has higher CP concentration than barley or wheat. Khorasani et al. (1997) found that at the boot stage, triticale and barley had higher CP concentrations than oats, but as maturity advanced, the CP concentration decreased in all species, and when harvested at the soft dough stage there were no differences between the cereals. For whole crop silage it is typical that the CP concentration is not very high and mostly it is lower than moderately digestible grass silage (Huhtanen et al. 2006, Huuskonen and Joki-Tokola 2010, O'Kiely 2011, Huuskonen et al. 2020). In the whole data of the present experiment the CP concentration varied from $81 \mathrm{~g} \mathrm{~kg}^{-1} \mathrm{DM}$ to $106 \mathrm{~g} \mathrm{~kg}^{-1} \mathrm{DM}$.

In our data from 2017, the highest NDF concentration was found in the wheat and triticale varieties. This result is in line with the experiments by Huuskonen et al. (2020) and Khorasani (1997), in which the NDF concentration of triticale was found to be higher compared to barley when whole crops were harvested at the soft dough stage. Nadeau (2007) reported that triticale had the lowest NDF concentration whereas oats and wheat had the highest when harvested at the early dough stage. In our data from 2018 no clear differences in the NDF concentration between the species were found, which indicates the variation between the years. Typically, the NDF concentration is affected by stage of maturity and the ear:stem ratio as the cell walls are primarily in the plant stem (Khorasani 1997, Nadeau 2007, Wallsten et al. 2010). However, when observing data from 2018, there was a clear differences in ear:stem ratio but not in NDF concentration between the varieties.

In the present experiment, the triticale variety Bikini had a high WSC concentration, low starch concentration in the ears and a low ear:stem ratio. This may indicate that the Bikini variety was harvested too early in the growth stage, although all varieties were assessed to be at the soft dough stage when harvested by following the kernel development according to the Zadoks growth scale (Zadoks et al. 1974). If the Bikini variety was harvested at too early of a stage, it also may have contributed to the low DM yield. According to Givens et al. (1993), the assessment of the growth stage alone may not be a good guide to the composition and digestibility of whole crop cereal silage.They concluded that it is a subjective technique and in addition, other factors, such as variety and agronomic practises, particularly cutting height, may also have an influence on the composition and digestibility.

There were significant differences in the fractions of stems, leaves and ears between the crop varieties. For all varieties, the proportion of leaves was substantially lower than the proportion of ears and stems. Then although the leaves had high digestibility, the effects on the chemical composition and nutritive values of the whole biomass was rather small. Except for the triticale variety Nagano, triticale had a higher proportion of stems compared to barley, which is similarly to the findings by Khorasani et al. (1997).

In 2017 both barley varieties had higher D-values than the triticale and wheat varieties, and this result is in line with previous experiments by Huuskonen et al. (2020). Also, Cherney and Marten (1982) reported higher in vitro digestibility in barley compared to oats, wheat and triticale. Similarly, Nadeau (2007) observed that barley but also triticale had higher in vitro digestibility than oats and wheat. However, in 2018 a similar difference was not found. Previously, it has been found that the growth stage and in consequence, the ear:stem ratio are factors that mostly affect the chemical composition and digestibility of whole crop silage (Khorasani et al. 1997, Nadeau 2007, Rustas 2009). However, in the present experiment, the ear:stem ratio did not clearly affect the digestibility of the crops as differences in the digestibility of the fractions compensated for the differences in the ear:stem ratio. This result is in line with a previous study by Sinclair et al. (2003) in which increasing the cutting height of whole crop wheat at harvest did not affect the apparent digestibility determined by using sheep. Although in the present experiment there were differences in the ear:stem ratio, only the barley varieties Kaarle and Trekker differed in terms of their digestibility: the Trekker variety had a higher D-value even though the Kaarle variety had a higher ear:stem ratio. The result is probably due to clearly higher solubility of the stems in the Trekker variety. However, the barley varieties Armas and Kaarle, which had the highest ear:stem ratio, also had the highest pepsin-cellulase solubility for the ears but the lowest solubility for the stems and leaves. The lowest ear:stem ratio was found for the triticale varieties Bikini and Somtri, and they also had the lowest pepsin-cellulase solubility for the ears. However, a higher proportion of stems and particularly higher digestibility of the stem and leaves compensated for the lower digestibility of the ears and they did not differ from the others when assessed by the D-value. The results of the present experiment support the conclusion by Sinclair et al. (2003) that showed that the proportion of stems is not a major factor limiting the ME value of the forage which actually results from the digestibility.

\section{Effects of fertilizer and seed rate on the yield of the ley}

It was hypothesized that reduced seed and fertilization rates could prevent the lodging of the cereals used as nurse crops for the undersown new ley and subsequently promote grass growth. Because the cereal crops did 
not lodge, the hypothesis could not be evaluated. However, theoretically this method could be used as an insurance against lodging and the cost is about $1175 \mathrm{~kg} \mathrm{DM} \mathrm{ha}^{-1}$ in terms of the reduced cereal crop yield. However, when assessing the costs, it also should be taken into account that production cost was reduced, due to less fertilizer and seed. In the first production year, the total DM yield and density of the ley sward in the spring were good and the treatment with reduced fertilizer and seed rate did not affect them. The crop varieties did also not affect the growth of undersown ley.

\section{Calculation of whole crop silage production costs}

The differences in the production costs of different silage types were lower than expected. Whole crop silage has to be established annually, while grass ley can be assumed to be established every third year in northern conditions. Seed, fertilizer, and harvest costs differ greatly between silage types. The costs contradicted each other so that finally the production costs did not differ to a great extent, although the calculation is sensitive to yield assumptions. For example, if the yield of grass ley rose to $10000 \mathrm{~kg} \mathrm{DM} \mathrm{ha}^{-1}$ and the other silage types remained at the mid-level, the production costs of grass silage would be clearly the cheapest ( $\left.0.15 \mathrm{EUR} \mathrm{kg}^{-1} \mathrm{DM}\right)$. In this calculation DM yields did not represent the final silage DM yields because they did not include harvest, storage and ensiling losses. However, these losses may be substantial and different depending on harvest method and ensiling process. They also may vary widely that makes it difficult to assess the amount of losses in the calculation. The calculation mainly indicates that when using average assumptions, the annual whole crop silages are not significantly more expensive to produce than perennial grass silage.

When comparing production costs of different silage types, it is essential to notice that these silage types have very different values in terms of animal feeding. For example, barley whole crop silage has a different value for dairy feeding than high quality grass silage. Whole crop cereal silage can play an important role as a component in mixed ration feeding.

The production costs of whole crop silage types can be compared also to commercial feed prices. In this case, subsidies based on field areas should be taken into account. These subsidies would reduce the prices of silage considerably in our production costs calculation.

\section{Conclusions}

Varieties of triticale can produce high DM yields and it does not differ substantially in nutritive value from barley and wheat. All the studied species and varieties in this research were suitable raw materials for whole crop silage. However, due to the variation between the years, more experiments are needed to find generally applicable differences between the varieties. High DM yield of the ley in the first production year was possible to achieve using small grain cereals as a nurse crops and harvest them as a whole crop. Under the current circumstances, the reduced cereal seed and fertilization rates did not affect the yield of the undersown ley. The production costs of the different whole crop silage types were surprisingly similar.

\section{Acknowledgements}

This study was partially funded by the Centre for Economic Development, Transport and the Environment for Northern Ostrobothnia, Oulu, Finland, Eastman Chemical Company, Berner Ltd and Hankkija Ltd. The authors thank Research Professor Marketta Rinne for valuable comments on the manuscript. We wish to express our gratitude to Mr. Jarkko Kekkonen and his personnel for their technical assistance.

\section{References}

Berkenkamp, B. \& Meeres, J. 1987. Mixtures of annual crops for forage in central Alberta. Canadian Journal of Plant Science 67: 175-183. https://doi.org/10.4141/cjps87-021

Cazzato, E., Laudadio, V. \& Tufarelli, V. 2012. Effects of harvest period, nitrogen fertilization and mycorrhizal fungus inoculation on triticale (xTriticosecale Wittmack) forage yield and quality. Renewable Agriculture and Food Systems 27: 278-286. https://doi.org/10.1017/S1742170511000482

Cherney, J.H. \& Marten, G.C. 1982. Small grain crop forage potential: I. Biological and chemical determinants of quality, and yield. Crop Science 22: 227-231. https://doi.org/10.2135/cropsci1982.0011183X002200020007x 
Givens, D.I., Moss, A.R. \& Adamson, A.H. 1993. The digestion and energy value of whole crop wheat treated with urea. Animal Feed Science and Technology 43: 51-64. https://doi.org/10.1016/0377-8401(93)90142-7

Hakala, K., Nikunen, H.-M., Sinkko, T. \& Niemeläinen, O. 2012. Yields and greenhouse gas emissions of cultivation of red clovergrass leys as assessed by LCA when fertilised with organic or mineral fertilisers. Biomass and Bioenergy 46: 111-124. https://doi.org/10.1016/j.biombioe.2012.09.021

Huhtanen, P., Nousiainen, J. \& Rinne, M. 2006. Recent developments in forage evaluation with special reference to practical applications. Agricultural and Food Science 15: 293-323. https://doi.org/10.2137/145960606779216317

Huhtanen, P., Rinne, M. \& Nousiainen, J. 2007. Evaluation of the factors affecting silage intake of dairy cows; a revision of the relative silage dry matter intake index. Animal 1: 758-770. https://doi.org/10.1017/S175173110773673X

Huuskonen, A., Jaakkola, S. \& Manni, K. 2020. Intake, gain and carcass traits of Hereford and Charolais bulls offered diets based on triticale, barley and grass silages. Agricultural and Food Science 29: 318-330. https://doi.org/10.23986/afsci.89813

Huuskonen, A. \& Joki-Tokola, E. 2010. Performance of growing dairy bulls offered diets based on silages made of whole-crop barley, whole-crop wheat, hairy vetch and grass. Agricultural and Food Science 19: 116-126. https://doi.org/10.2137/145960610791542325

Huuskonen, A., Pesonen, M. \& Joki-Tokola, E. 2017. Feed intake and live weight gain of Hereford bulls offered diets based on whole-crop barley and whole-crop wheat silages relative to moderate digestible grass silage with or without protein supplementation. Annals of Animal Science 17: 1123--1134. https://doi.org/10.1515/aoas-2017-0007

Keady, T.W.J. 2005. Ensiled maize and whole crop wheat forages for beef and dairy cattle: effects on animal performance. In: Park, R.S. \& Stronge, M.D. (eds.). Silage production and utilization technology. Proceedings of the XIVth International Silage Conference, Belfast, Northern Ireland. p. 65-82.

Khorasani, G.R., Jedel, P.E., Helm, J.H. \& Kennelly, J.J. 1997. Influence of stage of maturity on yield components and chemical composition of cereal grain silages. Canadian Journal of Animal Science 77: 259-267. https://doi.org/10.4141/A96-034

Kuoppala, K., Rinne, M., Lötjönen, T. \& Huuskonen, A. 2014. Palkokasveja sisältävien kokoviljasäilörehujen rehuarvon tarkentaminen ruokinnan optimoimiseksi. In: A. Huuskonen. (ed.). Edistystä luomutuotantoon -loppuraportti. MTT Raportti 175. p. 37-50.

Kuoppala, K., Rinne, M., Lötjönen, T. \& Huuskonen, A. 2015. Digestibility of whole crop legume-cereal silages harvested at three different dates. In: J.L.P. Daniel, G. Morais, D. Junges and L.G. Nussio. (eds.). International symposium on forage quality and conservation. Proceedings of the XVII international silage conference, São Paulo, Brazil. p. 286-287.

Li, C.J., Xu, Z.H., Dong, Z.X., Shi, S.L. \& Zhang, J.G. 2016. Effects of nitrogen application rate on the yields, nutritive value and silage fermentation quality of whole-crop wheat. Asian-Australasian Journal of Animal Science 29: 1129-1135. https://doi.org/10.5713/ ajas.15.0737

Luke 2020. Feed Tables and Nutrient Requirements. Natural Resources Institute Finland (Luke), Helsinki, Finland. http://www. luke.fi/feedtables. (Cited 15 July 2020).

MAFF 1984. Energy Allowances and Feeding Systems for Ruminants. ADAS Reference book 433. Ministry of Agriculture, Fisheries and Food. Her Majesty's Stationery Office, London. 85 p.

Nadeau, E. 2007. Effects of plant species, stage of maturity and additive on the feeding value of whole-crop cereal silage. Journal of the Science of Food and Agriculture 87: 789-801. https://doi.org/10.1002/jsfa.2773

Nousiainen, J., Rinne, M., Hellämäki, M. \& Huhtanen, P. 2003. Prediction of the digestibility of the primary growth of grass silages harvested at different stages of maturity from chemical composition and pepsin-cellulase solubility. Animal Feed Science and Technology 103: 97-111. https://doi.org/10.1016/S0377-8401(03)00206-2

O'Kiely, P. 2011. Intake, growth and feed conversion efficiency of finishing beef cattle offered diets based on triticale, maize or grass silages, or ad libitum concentrate. Irish Journal of Agricultural and Food Research 50: 189-207. https://doi.org/10.2307/41549251.

Palva, R. 2019. Konetyön kustannukset ja tilastolliset urakointihinnat (Costs of machine works and statistics of contractor prices). TTS:n julkaisuja 447. Työtehoseura ry. 16 p. (in Finnish).

Peltonen-Sainio, P., Jauhiainen, L., Hakala, K. \& Ojanen, H. 2009. Climate change and prolongation of growing season: changes in regional potential for field crop production in Finland. Agricultural and Food Science 18: 171-190. https://doi.org/10.2137/145960609790059479

ProAgria 2019. Esimerkkilaskelmia tuotantokustannuksista (Model calculations of production costs). Maatalouskalenteri 2020: 157-167. (in Finnish).

Rustas, B.-O. 2009. Whole-crop cereals for growing cattle. Effects of maturity stage and chopping on intake and utilisation. Doctoral Thesis. Swedish University of Agricultural Sciences, Skara, Sweden. 60 p.

Salo, M.-L. \& Salmi, M. 1968. Determination of starch by the amyloglucosidase method. Journal of the Scientific Agricultural Society of Finland 40: 38-45. https://doi.org/10.23986/afsci.71697

Sinclair, L.A., Wilkinson, R.G. \& Ferguson, D.M.R. 2003. Effects of crop maturity and cutting height on the nutritive value of fermented whole crop wheat and milk production in dairy cows. Livestock Production Science 81: 257-269.

https://doi.org/10.1016/S0301-6226(02)00261-0

Wallsten, J., Bertilsson, J., Nadeau, E. \& Martinsson, K. 2010. Digestibility of whole-crop barley and oat silages in dairy heifers. Animal 4:3: 432-438. https://doi.org/10.1017/S1751731109991212

Zadoks, J.C., Chang, T.T. \& Konzak, C.F. 1974. A decimal code for the growth stages of cereals. Weed Research 14: 415-421. https://doi.org/10.1111/j.1365-3180.1974.tb01084.x 


\section{Appendix}

Production costs of various types of silage. Clover-timothy ley was assumed to be established with the nurse crop and it was expected to be grown for three years. The machine work was assumed to be done by contractors.

\begin{tabular}{|c|c|c|c|c|c|c|c|}
\hline & $\begin{array}{l}\text { Fertilizer } \\
\mathrm{N} \mathrm{kg} \mathrm{ha}^{-1}\end{array}$ & $\begin{array}{l}\text { Costs } \\
\text { EUR kg-1 }\end{array}$ & $\begin{array}{l}\text { Amount } \\
\mathrm{kg} \mathrm{ha}^{-1}\end{array}$ & $\begin{array}{c}\text { Faba bean + } \\
\text { wheat silage } \\
\text { EUR ha-1 }\end{array}$ & $\begin{array}{l}\text { Barley- silage } \\
\text { EUR ha-1 }^{-1}\end{array}$ & $\begin{array}{l}\text { Triticale- silage } \\
\text { EUR ha-1 }\end{array}$ & $\begin{array}{c}\text { Clover }+ \\
\text { timothy silage } \\
\text { EUR ha-1 }^{-1}\end{array}$ \\
\hline \multicolumn{4}{|c|}{ Ploughing, seedbed tillage, sowing } & 202 & 202 & 202 & 0 \\
\hline \multicolumn{8}{|l|}{ Seed costs } \\
\hline Faba bean & & 0.88 & 250 & 220 & & & \\
\hline Wheat & & 0.49 & 100 & 49 & & & \\
\hline Barley & & 0.45 & 200 & & 90 & & \\
\hline Triticale & & 1.05 & 250 & & & 263 & \\
\hline Clover + timothy & & 4.70 & 8 & & & & 38 \\
\hline \multicolumn{8}{|l|}{ Fertilizer, NPK (22-5-5) } \\
\hline Faba bean + wheat & 50 & 0.40 & 227 & 91 & & & \\
\hline Barley & 90 & 0.40 & 409 & & 164 & & \\
\hline Triticale & 90 & 0.40 & 409 & & & 164 & \\
\hline Clover + timothy & 180 & 0.40 & 818 & & & & 327 \\
\hline \multicolumn{4}{|c|}{ Silage additive + silage film } & 58 & 58 & 58 & 58 \\
\hline \multicolumn{8}{|c|}{ Harvest to the clamp silo } \\
\hline \multicolumn{4}{|c|}{ Faba bean: mowing + pick up harvester } & 200 & & & \\
\hline \multicolumn{4}{|c|}{ Barley and triticale: direct cut harvester } & & 220 & 220 & \\
\hline \multicolumn{4}{|c|}{ Grass ley: mowing + pick up harvester $\times 2$} & & & & 400 \\
\hline \multicolumn{4}{|c|}{ Interest of working capital (50\%, 5\%) } & 21 & 18 & 23 & 11 \\
\hline \multicolumn{4}{|l|}{ Costs of clamp silo } & 219 & 219 & 219 & 219 \\
\hline \multicolumn{4}{|l|}{ Costs of field } & 416 & 416 & 416 & 416 \\
\hline \multicolumn{4}{|l|}{ Overhead costs } & 66 & 66 & 66 & 66 \\
\hline \multicolumn{4}{|l|}{ Total costs } & 1542 & 1453 & 1630 & 1535 \\
\hline \multicolumn{4}{|c|}{ Estimated yield range, $\mathrm{kg} \mathrm{DM} \mathrm{ha}^{-1}$} & 7000-9000 & $6500-8500$ & $8000-10000$ & 7000-9000 \\
\hline \multicolumn{4}{|l|}{ Costs, EUR kg ${ }^{-1} \mathrm{DM}$} & $0.22-0.17$ & $0.22-0.17$ & $0.20-0.16$ & $0.22-0.17$ \\
\hline \multicolumn{4}{|l|}{ Mean yield, kg DM ha-1 } & 8000 & 7500 & 9000 & 8000 \\
\hline \multicolumn{4}{|l|}{ Costs, EUR kg-1 DM } & 0.19 & 0.19 & 0.18 & 0.19 \\
\hline
\end{tabular}

